\section{IgA serum levels and disease activity in ankylosing spondylitis}

SIR, I read with considerable interest the report by Franssen and associates of a prospective study of $\operatorname{IgA}$ serum levels and disease activity in ankylosing spondylitis (AS). ${ }^{1}$ In their comparative trial of phenylbutazone and diflunisal, serum $\operatorname{IgA}$, erythrocyte sedimentation rate, and disease activity all decreased during regular drug treatment, suggesting a disease modifying effect of the nonsteroidal anti-inflammatory drugs (NSAIDs) in AS.

That NSAIDs affect favourably the natural course of AS is not widely appreciated. ${ }^{2}$ In fact this concept first became clear to me after completion of a five year trial of indomethacin in 28 patients that dates back to $1968 .^{3}$ As judged by several criteria, including articular pain, duration of morning stiffness, onset of fatigue, and joint mobility, the overall response to indomethacin was rated as good in 21 patients, fair in five, and poor in two. After receiving indomethacin for an average period of 33 months, 21 of the 28 patients were in the American Rheumatism Association functional class $\mathrm{I}^{4}$ Only one patient had been so classified before the drug trial. The average Westergren erythrocyte sedimentation rate values for all 28 patients decreased during the drug trial from 39 to $26 \mathrm{~mm} / \mathrm{h}(\mathrm{p}<0 \cdot 01$, Student's $t$ test $)$. Indomethacin was discontinued in three patients-in two because of a poor response to the drug and in one because of an adverse reaction. Clearly, the results of this trial suggest that indomethacin favourably alters the course of AS.

In 1981, 18 years after the first patients were entered into this trial, it was possible to locate and reassess 14 of the remaining 25 patients. ${ }^{5}$ Of the 14 , four had achieved remission and required no further drug therapy. Indomethacin had been discontinued in four patients - in two because of gastrointestinal side effects and in two because of a more favourable effect from another NSAID. The remaining six patients continue to receive indomethacin at an average daily dosage of $100 \mathrm{mg}$ (range $75-100 \mathrm{mg}$ ) and continue to benefit from its long term use.

Division of Rheumatology,

J J CALABRO

Saint Vincent Hospital,

Departments of Medicine and Pediatrics,

University of Massachusetts Medical School,

Worcester, Massachusetts,

USA

\section{References}

1 Franssen M J A M, Van De Putte L B A, Gribnau F W J. IgA serum levels and disease activity in ankylosing spondylitis: a prospective study. Ann Rheum Dis 1985; 44: 766-71.

2 Calabro J J. Sustained-release indomethacin in the management of ankylosing spondylitis. Am J Med 1985; 79 (suppl 4C): $39-51$.

3 Calabro J J, Amante C M. Indomethacin in ankylosing spondylitis. Arthritis Rheum 1968; 11: 56-64.

4 Steinbrocker O, Traeger C H, Batterman R C. Therapeutic criteria in rheumatoid arthritis. JAMA 1949; 140: 659-62.

5 Calabro J J. Appraisal of efficacy and tolerability of Indocin (indomethacin, MSD) in acute gout and moderate to severe ankylosing spondylitis. Semin Arthritis Rheum 1982; 12 (suppl 1): $112-6$.

\section{Idiopathic haemarthrosis with chondrocalcinosis}

SIR, We read with interest the article by Woolf $e$ t al about the idiopathic haemorrhagic rupture of the shoulder in destructive disease of the elderly.'

In our experience haemarthrosis may also be associated with articular chondrocalcinosis and joint destruction. ${ }^{23}$

We have reviewed 28 patients with haemarthrosis in 32 joints ( 20 knees and 12 shoulders). ${ }^{4}$ Periarticular ecchymosis was found in only one case relating to the knee but in four cases relating to the shoulder. There were calcium pyrophosphate dihydrate microcrystals in the shoulder fluid in eight cases but typical calcification of the joint in only three cases. Degenerative radiological changes with rupture of the rotator cuff were common, but in three cases the presentation was that of a neuropathic joint.

Patients who did not improve with rest, aspiration of the effusion, and intra-articular injection of steroids were treated by radioisotopic synoviorthese. ${ }^{5}$ In these patients, after injection of $2-3 \mathrm{mCi}$ of gold-198 (four cases) or rhenium-186 (nine cases), the shoulder effusions disappeared in 11 cases (mean follow up of four years).

Persistence of pain after treatment in most cases was thought to be due to degenerative lesions.

Service de Rhumatologie 'A',

CHARLES-JOËL MENKÈS

Hôpital Cochin, JACQUES RONDIER

27 rue du Fg St-Jacques,

75674 Paris,

France

\section{References}

1 Woolf A D, Cawston T E, Dieppe P A. Idiopathic haemorrhagic rupture of the shoulder in destructive disease of the elderly. Ann Rheum Dis 1986; 45: 498-501.

2 Menkès C J, Simon F, Delrieu F, et al. Destructive arthropathy in chondrocalcinosis articularis. Arthritis Rheum, 1976; 19 (suppl): $329-48$.

3 Villiaumey J, Galle P, Amouroux J. Arthropathies lytiques et chondrocalcinose articulaire. Semin Hôp (Paris) 1974; 50: 3175-90.

4 Cayla J, Huchet B, Rondier J, Menkès C J. Hémarthroses de la chondrocalcinose articulaire. Rev Rhum Mal Osteoartic 1982; 49: $281-5$.

5 Menkès C $\mathrm{J}$. Is there a place for chemical or radiation synovectomy in rheumatic diseases? Rheumatol Rehabil 1979; 2: 65-77.

\section{Connective tissue deposits in MRL/1 mice}

SIR, The article on connective tissue abnormalities in MRL/1 mice published by Edwards et al in the Annals ${ }^{1}$ is very interesting. The description of morphological changes in the connective tissue confirms our observations on arthritis in the MRL/1 mouse that we published in 1985. ${ }^{2}$

In our study of 58 animals of different ages and sex we 